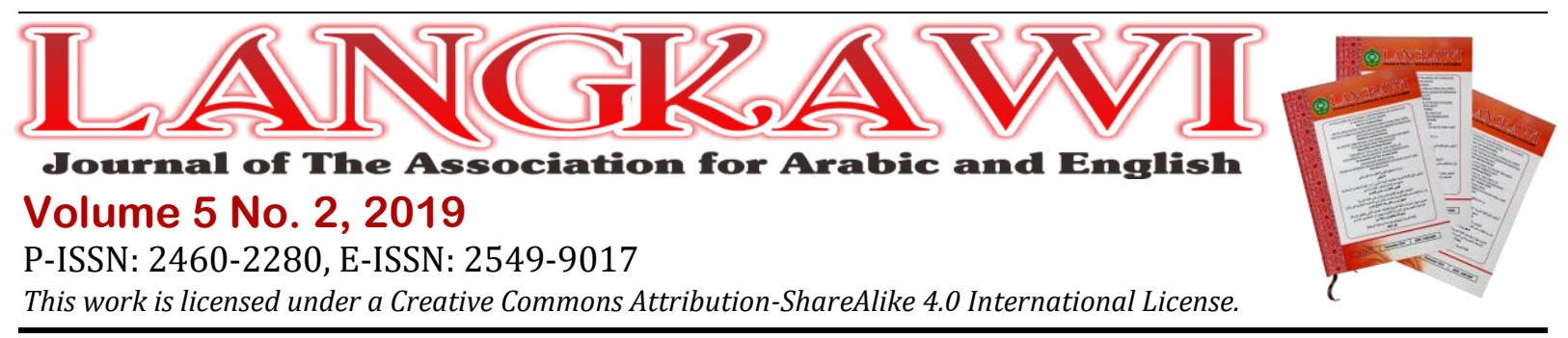

\title{
The Effect on Interactive Board Games (IBG) on Vocabulary Achievement
}

\author{
Endang Sulistianingsih ${ }^{1}$, Rizka Febriani' ${ }^{2}$, JCS. Pradjarto ${ }^{3}$ \\ ${ }^{1}$ Universitas Pancasakti Tegal, Indonesia. E-mail: endang.sulistia@gmail.com \\ 2Universitas Pancasakti Tegal, Indonesia. E-mail: rizkafe91@gmail.com \\ ${ }^{3}$ Universitas Pancasakti Tegal, Indonesia. E-mail: totopradjarto@gmail.com
}

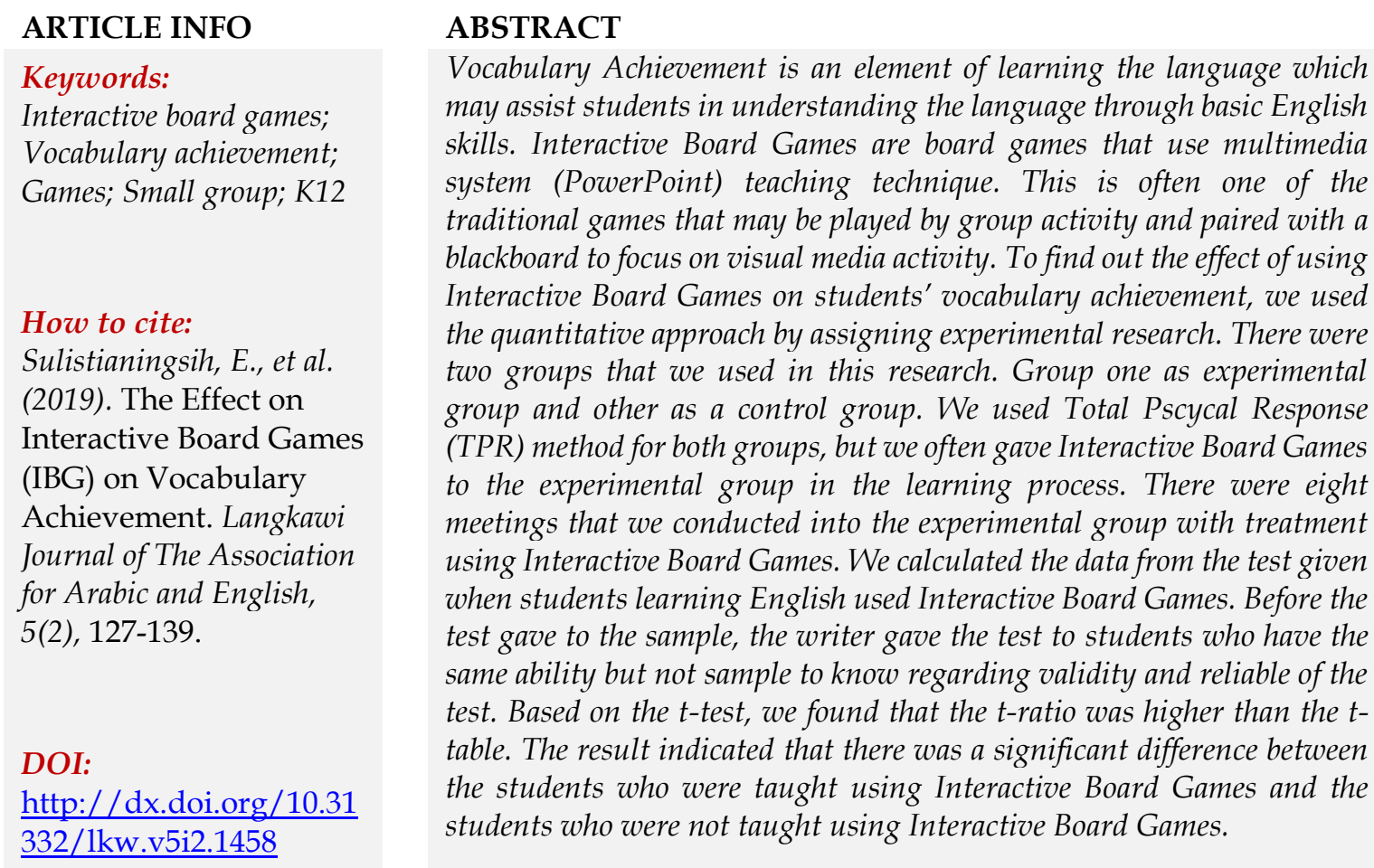

\section{Introduction}

Vocabulary is a crucial part of learning language, especially in learning and teaching English, besides the other components such as grammar. Vocabulary Achievement is a component of language learning that may help students in understanding the language that has four basic skills. Vocabulary help students to develop their language through the four skills, such as reading, writing, listening, and speaking. As Nation (2002); Cahyono (2015), say that vocabulary development is as such a crucial part of language acquisition that it deserved to be planned for, deliberately controlled, and monitored. So, vocabulary achievement is a tool to facilitate students to increase their language skills.

Learning English at Junior High School should be a fun activity. It is because, during these grades, the characteristics of students get bored quickly. They also tend to shy and sometimes afraid of asking and expressing their ideas. Several factors make them bored, such as time, situation, exhausting material, etc. They need some way of the solutions that will not make them bored with learning English. The preliminary observation is conducted at the second-grade of Junior High School in Tegal. The result 
shows that students have a decent ability to learning English. Also, some of the students are active while others are passive in-class activities. They often feel bored during the activities that continue the same and too serious. They feel that having basic English exercises to complete during learning activities not only make them bored but also depressed. Therefore, they need some way of a solution that makes them feel fun, easy and not boring. Dewaele \& Thirtle (2009) say that foreign language learning can be succeeded as long as it is fun, exciting, and achievable. They add that teenagers' foreign learners should be given not only linguistics but also psychological support.

Games are often one of solution for the teacher to create more active and creative learning activities. Some experts say that using the game in learning is often stirred up students to be more interested in what they learn (Hur \& Suh, 2012; Huyen \& Nga, 2003; Young \& Wang, 2014). Teachers also can use the games to create a fun atmosphere for the students in doing some exercises. There are several games teachers can employ in learning activities, such as card games, role-playing games, etc. Among those games which are exciting and challenging are Interactive Board Games. During these games, students learn more to complete some cases of the latest vocabulary to make them a winner. So, they are going to learn English vocabulary without feeling depressed and dull.

Interactive Board Game is a board game that uses multimedia system (PowerPoint) teaching technique. This is often one among traditional games that may be competed by group activity and paired with black-board to focus on visual media activity. According to Durden, Dangel, Durden, \& Dangel, (2008); (Wasik, 2014); Siegler and Hitti (2012) state that a little group activity is a perfect context for competing board game because teacher guide students to fulfill specific instructional goals by extending students learn vocabulary throughout playing the game. This is often one effective way of learning language, especially learning a foreign language. The procedure of the Interactive Board Games in learning and teaching activities adapted the ADDIE steps by Branch (2009). The procedure is analyzed, design, develop, implement, and evaluate. The concept proposed by Branch (2009) emphasizes on students center learning, innovative, authentic and inspirational.

Based on the initial research on one of the Junior High School students in Tegal city, Central Java Indonesia, we find that the reason why the students feel difficulty in learning English is that their vocabulary is poor. Moreover, they even get more depressed and boring and also have less motivated when their teachers teach vocabulary in a traditional way. So, this study tries to find out whether Interactive Board Games influences students' vocabulary Achievement of Junior High School or not.

\section{Literature Review}

a. Vocabulary Achievement

Vocabulary is a very important part of learning language, particularly in learning and teaching English, besides the other components such as Grammar. As Nation (2002); Cahyono (2015), state that vocabulary growth is such a crucial part of language acquisition that it deserves to be planned for deliberately controlled and monitored. During this case, vocabulary will growth to helps students in getting language acquisition. So, vocabulary is often calculated to be set up for deliberately 
controlled and monitored in learning English. It will help the teacher to understand how far their students' achievement and the way to facilitate them to develop their language skills further.

Evelyn and Brown (1995); Rohmatillah (2014), define vocabulary as a list of words for a listing or a group of a word which individual speakers of language would possibly use. The students will develop their skills in learning English by acquiring new words through learning activities such as speaking, listening, writting and reading. Then the students perceive those new words, not only knowing its meaning on their mothertongue but also they have to seek out how to use those words in some contexts. After that, the student use those words in their daily lives. In addition, Richards and Renandya (2002); Destianingsih et al. (2017), in their research state that essential vocabulary element of language knowledge and contribute a lot of basis for a way well learners speak, listen, read and write. So, vocabulary achievement will help students to raise their skills in learning a foreign language, particularly English.

According to Montgomery (2007) state that there are four kinds of vocabulary as listening, speaking, reading, and writing. Students lead to acquiring listening and speaking vocabularies a few years since they begin to create reading and writing vocabulary. So, kinds of vocabulary will help to develop different varieties. Students will develop different skills automatically once they can improve one kind of vocabulary. Such as, writing vocabulary might develop by speaking vocabulary. It means students will develop writing vocabulary when they develop their speaking vocabulary too. In conclusion, is that the development of one kind of vocabulary will affect one different kind of vocabulary.

The common type for the second grade of Junior High School students is reading vocabulary. According to Biemiller (2004); Reza (2012), define that vocabulary is deal with the oldest areas in the literacy of research, investigators declared which improvement in reading comprehension also could lead to the development of vocabulary achievement. During this case, vocabulary is a very important element that will support and also supported by English skills, during this space is reading. Students can get more comfortable to seek out new words in reading activities. However, students were also developing their reading comprehension by vocabulary too. So, that one among the explanations vocabulary is often an important part of learning English.

b. Interactive Board Games (IBG)

Interactive Board Games are board games that use multimedia system (PowerPoint) teaching technique. This is often one among traditional games that will be completed by group activity and paired with a blackboard to focus on visual media activity. According to Durden et al. (2008); Wasik, (2014); Siegler and Hitti (2012) stated that a little group activity is a perfect context to compete board game because the teacher might be guiding and directed to fulfill specific instructional goal by extending students learn throughout and when playing the game. This is often one effective way of learning a language, especially a foreign language. It means during a little group activity, the students more active and concentrates on playing the game, and this is often because students will not feel disturbed by other students as if they are in a large 
group. Besides that, the teacher may also use his role as guide and director to assist students in understanding the material during and when they were playing the game.

The procedure of Interactive Board Games in learning and teaching activities the ADDIE steps by Branch (2009). There are the ADDIE steps, as follows; analyze, design, develop, implement and evaluate. The procedure that started concerning analyze to understand the students' personal information, the goal of the students learning English, target needs, and learning needs. The need analysis conducted using queries from the respondents that use the interview or multiple-choice form. The results of the questionnaires will help the teacher to create a design of games in language learning techniques.

The second procedure is the design. The design of board games includes the elements of the game board and instructions cards. The primary element is the game board. It created the students to focus on the learning process by the games. Whereas the cards instruction is an element that used to students' activities such as describe, give explain, etc. The third procedure is developed. The teacher ought to developing media to support the games. Developing media are often embodied in several parts such as the theme of the games, created the visual image of media, rules of games, the activities within the games, and handbook for the teacher. It suggests that how the teacher can develop the design materials of the learning through the board game to develop students' vocabulary achievement in learning English.

After developing the design board games, we can implement it in class then. The implementing board game in class ought to based on the queries result that has before. The last procedure is to evaluate, and there is some part of the evaluate of the board game, such as a gap of the game that the teacher finds, the congruity the material with the students learning needs within the game, the discipline of doing the game (rules), etc.

The benefits of Interactive Board Games, that it will help students to keep important memory and increasing concepts in functioning. It is because within the game activities, students more concentrate on seeking out the answers of the objects in order that they can keep the information by themselves and developing the information to the other students. Whereas the games give the students a lot of concentrates, the students also get some treatment for learning in the classroom. The students should not be exhausting and frustrated. The students will have a lower risk of mental diseases by fun activities of the game. Then, the games facilitate students in increasing their skills in social communication and social relationships. These games can also help teachers to speed up students' responses since the game force the students to keep the mind more active and focused.

Conversely, there are disadvantages of Interactive Board Games among them is it make the students noisy and uncontrol during learning activities. It happens because the game makes them more interested in playing. So, they are going to speak a lot and moving position all of the time in the class. The game also takes more time to play in class. It is because the game has some procedures or rules to clarify before and trough activities. The teachers ought to be more frequently monitoring the students to require effectively in the activities. Teaching using the game in class makes the students feel ease and happy. However, it creates chaos and a lack of seriously during the learning process in the classroom. Students tend to be out of control. 


\section{Method}

To find out the effect of Interactive Board Games on students' vocabulary achievement, we used quantitative methodology as a research approach by applying experimental research. The writers calculated the data (numeric) from the test given when students learning English used Interactive Board Games. Before the test gave to the sample, we gave the test to the class, which has the same ability but not sample, to measure validity and reliable of the test. When the test was valid and reliable, we gave the test to be employed in the final test as data to calculate the t-test. To get the data, we used two group designs in the research. They were the experimental group and the control group. We used Total Physical Response to be implemented. TPR can facilities the students using physical movement to react to verbal input. We used TPR for each of the groups, but we often gave Interactive Board Games to the experimental group during the learning process.

The implementation of Interactive Board Games in class, as follows: First, we explained a material, such as Recount Text, then we instructed students to create a group consisting of 5-6 members. There were two groups of cards. One group of cards have contained action cards and the other group of cards contained the question cards. Each of the groups of cards taken by material that recently discussed. Then, we as a teacher described some instructions and ruled out the games such as 1) Created a group with 5-6 members, 2) Took a lottery paper to know the order of play, 3) Finished all question numbers 1-10 to get twenty points, 4) Finished all actions to argue ten extra points, 5) If the players may end all queries in one round of play, they could begin another time. Nevertheless, if they still not finished all it, they might be failing. 6) The groups will get one "Star" if they have done the questions.

As we had described above, the students ought to finish the questions cards and action cards by the games to win and get the bonus score, as followed:

Table 1. List of question and action cards

\section{The question cards}

\section{The action cards}

Ganish had an (1) _. . experience last Tell about your holiday in last year. holiday. (adventurous)

Ganish, her brother and her brother's Tell about your dream in two years friends (2) ... Jakarta in the afternoon by ago.

minibus. (left)

Ganish, her brother and her brother's friends (3) ... the minibus while her A food you ate in this morning for cousins drove a car. (boarded)

Ganish's cousins had (4) ... to days before, so the rafting guide had prepared the equipment. (reserved)

She waited for them and welcomed them politely. Then, they wore (5) ... and_safety helmets. (life jackets)

Mention one your friend and tell about he/she. 


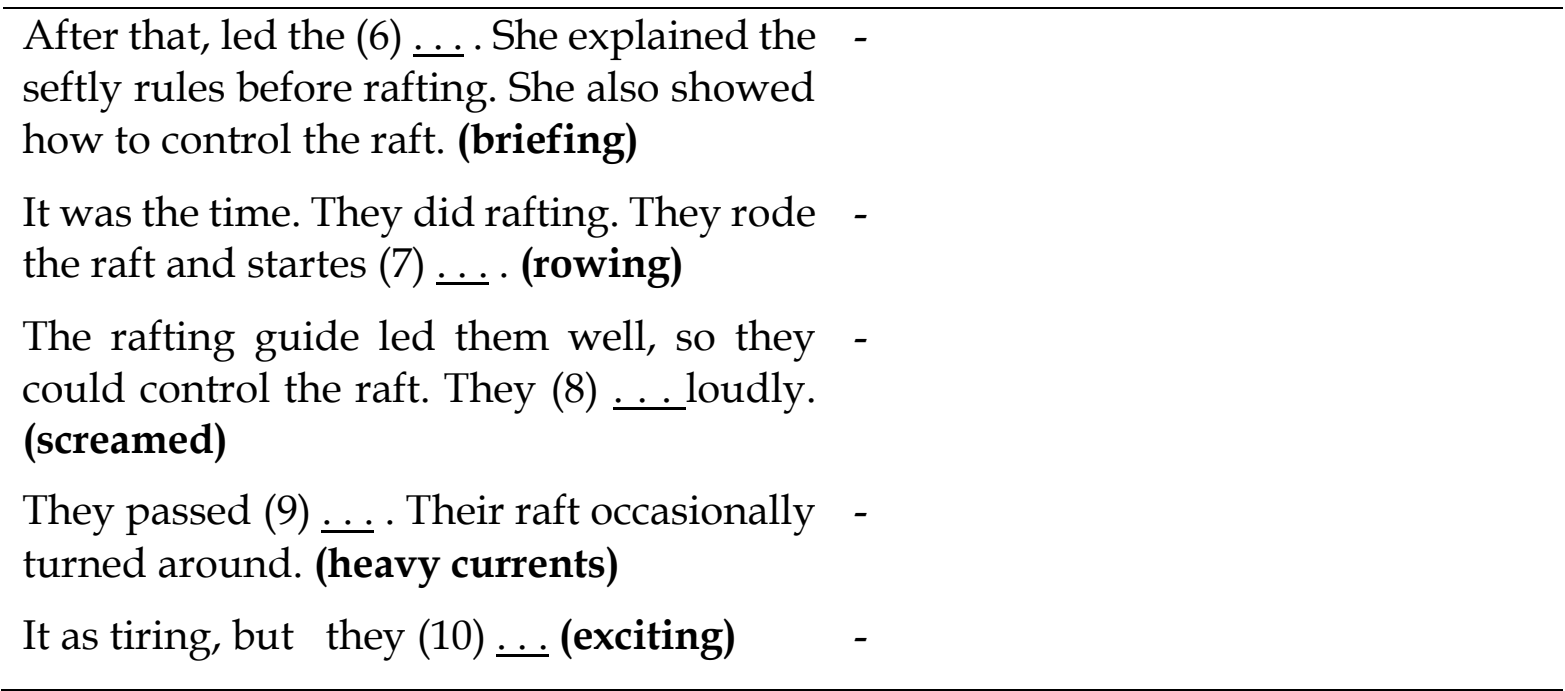

Table 1 describes the question and action cards that the writer used to design Interactive Board Games in class. The question and action cards, we used based on the syllabus, that consist of Recount text material.

After we described the rules, the students started to prepare a group. Then a member of the group would take a lottery to decide turn to play the games. After all, the group got the lottery, and we would instruct students to play the games. We just facilitated students when they got some trouble or confused about the games. In addition, we also gave some booster to students who still felt shy if they had to turn play.

The games would be finished if one of the groups could finish all questions and action cards. Nevertheless, the games would be finishing too, if the time was up. After the games wind up, we would give some evaluation of the students in games, such as told who the best group, who the best performance, or the winner furthermore that we would give some evaluated about the material of games, times, rules, etc.

\subsection{Participant}

The population of the study was all of the second-grade students of one of Juniors High School in Tegal in the academic year 2018/2019. There were 164 students in the second grade at one of Junior High School in Tegal, and that consist of six classes. While we took the sample by using a random cluster sampling technique to chose the class to be a sample from the second grade of one of Junior High School in Tegal. Then, we depended on them into two groups. One class as the experimental group and the other as the control group. The total number of sample was 52 students, with the number of each class was 26 students. While for the class group who used as the trial class, there were 28 students.

\subsection{Instrument}

We got the data about the effect of Interactive Board Games on Vocabulary Achievement of the second-grade students from the score of the final test as the instrument of the research. We used the vocabulary test in the final test that we gave to students. The test that students must do on the multiple-choice form, that consist of 50 number with four alternative answers, as followed: 


$\begin{array}{ll}\text { School } & : \text { One of Junior High School in Tegal } \\ \text { Subject } & : \text { English } \\ \text { Grade/Semester } & : \text { VIII / } 2 \\ \text { Topic } & : \text { Vocabulary } \\ \text { Time Allocation } & : 60 \text { Minutes }\end{array}$

Table 2. Instrument test

\begin{tabular}{cccccccccc}
\hline \multirow{3}{*}{ Topic } & $\begin{array}{c}\text { Levels of } \\
\text { Difficulty }\end{array}$ & \multicolumn{9}{c}{ Cevels of Cognitive } & \multicolumn{2}{c}{ Total } \\
& & C1 & C2 & C3 & C4 & C5 & C6 & \\
\hline \multirow{3}{*}{ Vocabulary } & Middle & 5 & 15 & 5 & - & - & - & 25 \\
& Difficult & 3 & 7 & 5 & - & - & - & 15 \\
\hline
\end{tabular}

Based on Table 2, there was a three-level cognitive domain that we choose to three levels of difficulty. The writers made 10 questions of recognition, 28 questions comprehension, and 12 questions of application. The total of the questions was 10 of an easy question, 25 of central questions, and 15 of a difficult question.

Before the test given to the sample class, we gave the test to the class that was not sampled class but had the same ability as the sample class. Then, we measured it to validity and reliability test. The class who used to measure the validity and reliable consist of 28 students. The writer used the validity of external and reliability with used the Spearman-Brown technique. The result of the validity test showed that the validity of $R_{t}$ to 28 is 0.374 , and $R_{0}$ to the test is 0.802 . It showed that $R_{0}$ higher than $R_{t}$, the result indicated that the test was Valid. While the result of the reliability test showed that $R_{11}$ was 0.408 , which had a higher value than $R_{t}$ for 28 , which is 0.374 , and the result indicated that the test was Reliable.

\subsection{Data Analysis}

To get the analysis of the data, we were using SPSS software formula and manual. There were hypotheses for this research. The hypothesis for the research was $\mathrm{H}_{0}$ accepted if the value of $t_{\text {count }}$ was lower than $t_{\text {table; }}$ meanwhile, $\mathrm{H}_{0}$ rejected if the

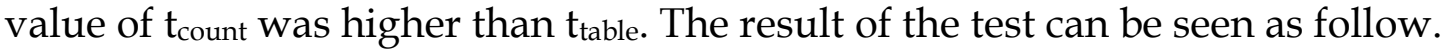

\section{Findings}

The research had been started March $6^{\text {th }}$ until April 16 ${ }^{\text {th }}$, 2019, in eight meetings to second grade at one of Junior High School in Tegal in the academic year 2018/2019. In this research, the materials made based on the syllabus, lesson plan, and instrument test. The two groups thought by the same materials. There were eight meetings for treatments. There are treatments that writer conducted in class, as follow:

The first meeting of the experimental group was held on March 18 2019. Before the lesson began, the writers introduced themselves and gave some explained about the purpose of teaching-learning activity on that day. The material for the first meeting was Past Continous Tense in Recount Text. The writers were explained about Past Continous Tense in the social function, structure of the text, and how to use Past 
Continous Tense with simple sentences to daily life. At the end of class, we give short explained about Interactive Board Games for the next meeting.

The second meeting of the experimental group was held on March 20th, 2019. The material still about Past Continous Tense in Recount Text. The writers explained the Past Continous Tense in positive, negative and interrogative structure text. After we explained the material, we made some groups of classes consist of 5-6 members. There were five groups in the class. Then, we gave some exercise about the material used Interactive Board Games. In the first treatment used Interactive Board Games, most of the students still felt unactive. They were more active in the learning activity the day before the writer used the games. They said that they still felt shy to perform in front of their friends. So, in the first treatment using IBG, the writers run out of times because we should give a boost to students to active.

The third meeting of the experimental group was held on March $25^{\text {th }}$, 2019. The material for the lesson was the recount text. The writers gave some text about recount text first. After that, we gave some questions about the text. Then we explained directly about recount text based on the text that was given before. The writers explained the social function, kind of the recount text, and generic structure of the text.

The fourth meeting of the experimental group was held on March 27th, 2019. The material still about recount text, but in this meeting, the writer would explain recount text language feature of Action Verb. The writer asked one or two students to speak in front of the class. Then, the writer helped the students to know directly about the story and added the story to the material. In the last minutes of class, we explained about Interactive Board Games to the next meeting, with different members and materials too in the games.

The fifth meeting of the experimental group as held on April $1^{\text {th }}$ 2019. The material still about recount text language features. Nevertheless, in this meeting, the students have to make some story about their experience in holiday and learned about Adverb and Adverbial Phrase in Recount text. After the students finished their exercise, we asked students to made some group consist of 5-6 members that must be different from the last members that they had. Then, the writers gave some text about the recount text. The students should finish some exercise about the text by using Interactive Board Games. The writers used the materials about the story of the students to give them exercise. In the second treatment used Interactive Board Games, the students more active. They have already to perform in front of the class without the booster from the writers. However, we still not have time enough to end the game. It was because they had more time to answer the question directly. They always back to the desk to looked dictionary to answer the questions.

The sixth meeting of the experimental group was held on $8^{\text {th }} 2019$. The material was factual recount text and Conjunction in Recount Text. The writers just explained about material directly, about social function, generic structure, and language features of the text. We also explained the differences in recount text based on personal experience and factual recount text.

In the seventh meeting of the experimental group held on April 10th, 2019. The material still about factual recount text and time connection in recount text. The writer gave some text about material first, then made students to 5-6 groups to finished some exercise used Interactive Board Game. The students should finish the exercise in the 
paper by group activity for 30 minutes. Then, at the end of the lesson, we announced whom the group has higher scores or points to get the winner. In the third treatment used Interactive Board Games, most of the students were more active. They were not shy and felt afraid to make some mistakes. The more ready to play when they got a turn to play. They had been could to answer the questions directly. So, we had time enough to end the game and announced the winner.

In the last meeting of the experimental group held on April 15th, 2019. The writers reviewed the first material that was given until the last material. The writers also gave blueprints directly to the final test in the next meeting. After that, we asked the students about how they are learning with IBG, most of the students answered they interested in learning English used games. And they want more a game to compare in their learning in class.

After the treatments and the materials had been given and explained. We did the final test for both groups, and they were the experimental and control group. The final test to experimental group was given on May $6^{\text {th, }}$ 2019, its the same day which the final test that given to the control group, but they did test at different time. The function of the final test was to know significant about vocabulary achievement between both groups as an experimental and control group. The instrument which we gave to both groups was the same.

There was a result for homogeneity of Pre-test, as followed:

Table 3. Test Result of Test Homogeneity of Variance

\begin{tabular}{llrrrr}
\hline & $\begin{array}{c}\text { Levene } \\
\text { Statistic }\end{array}$ & Df1 & Df2 & Sig. \\
\hline Pretest & Based on Mean & 1.159 & 1 & 50 & 0.287 \\
& $\begin{array}{l}\text { Based on Median } \\
\text { Based on Median }\end{array}$ & 0.118 & 1 & 50 & 0.732 \\
$\begin{array}{l}\text { and with adjusted } \\
\text { df }\end{array}$ & 0.118 & 1 & 39.072 & 0.733 \\
$\begin{array}{l}\text { Based on trimmed } \\
\text { mean }\end{array}$ & 0.450 & 1 & 50 & 0.506 \\
\hline
\end{tabular}

The result of the homogeneity test in the pre-test showed that sig based on mean is 0.287 was higher than 0.05 , which means the data was homogenous.

While the summary of the result of the test for the experimental and control group as follows:

Table 4. The Summary of the Result of Test for the Experimental and Control group

\begin{tabular}{ccc}
\hline Computation & Experimental Group & Control Group \\
\hline$N$ & 26 & 26 \\
$\bar{X}$ & 82 & 76 \\
$M e$ & 87 & 76 \\
\hline
\end{tabular}




\begin{tabular}{ccc}
\hline Mo & 90 & 74 \\
$S D$ & 8.50411 & 3.80525 \\
$S^{2}$ & 72.32 & 14.48 \\
\hline
\end{tabular}

Based on the table above, the experimental had mean 82 was higher than the control group had meant was 76 .

There was a result of the final test that we used of vocabulary test to the experimental and control group as follow:

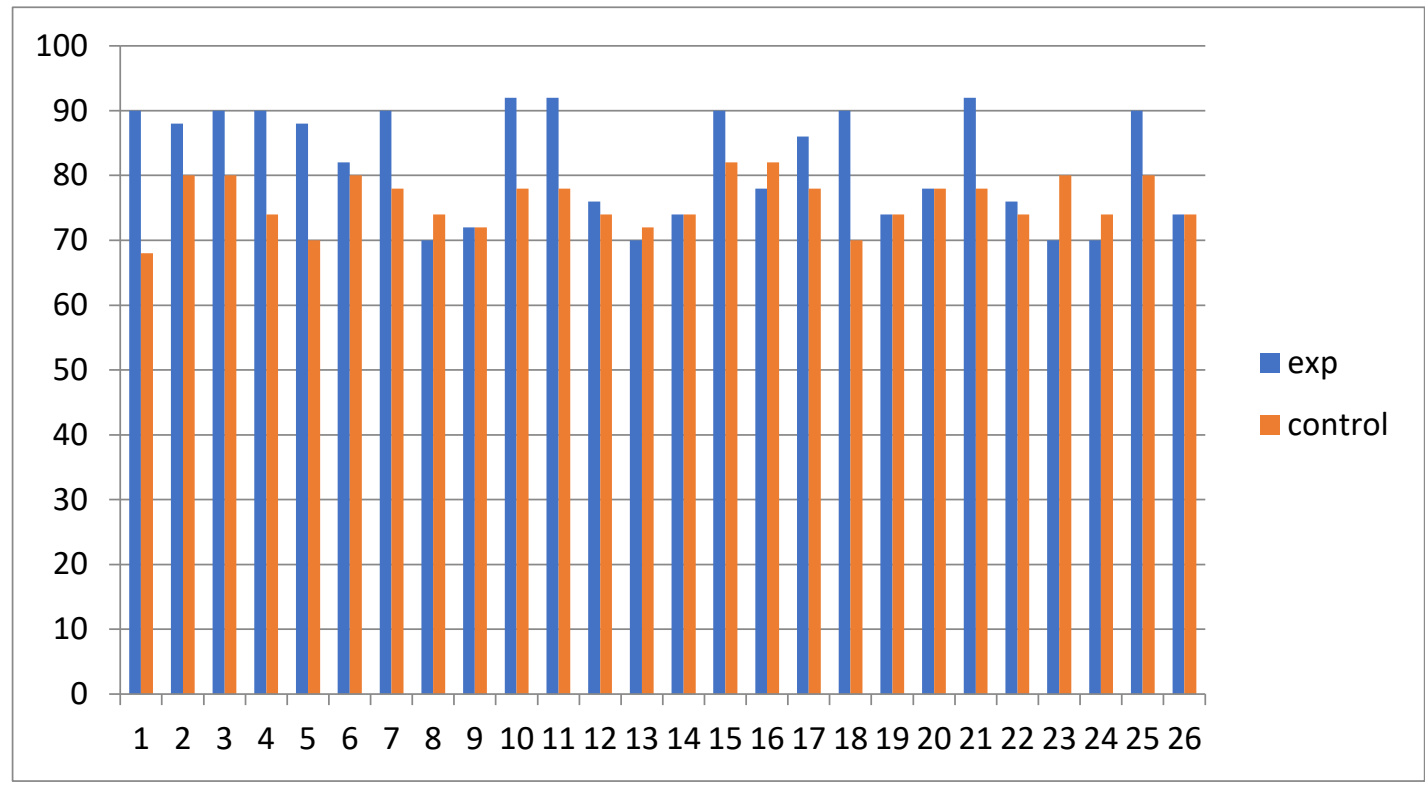

Graphic 1. The Result of Final Test in Experimental and Control Group

Based on the Graphic 1, that describes the result of the final test (vocabulary test) that we used to experimental and control group indicated which the experimental group had a higher score than the control group. We could see from the bluer that it was higher than the red color. Where the blue color indicated experimental group scores, and the red color indicated control group scores.

\section{Discussion}

There were eight meetings for both sample groups in this research, and there were three meetings that used Interactive Board Games to experimental in learning English.

In the first treatment used Interactive Board Games to the experimental group, we got some troubles. It was about the students had confused about the rules of games. It was because we did not give explained about the games the day before the implementation of the Interactive Board Games. So, they are confused about how to play the games, and how to solve the challenges of the games. On the other hand, they were embarrassed to come forward of the class individually as representatives if they have a turn to play. They needed more booster from the writer to performed in front of the class. It made the writers out of time to implement the games in class. This was reverse with the situation of the last day before they played the games. 
In the second treatment used Interactive Board Games to the experimental group, the students were more active. They have already to perform in front of the class. However, we still have trouble with the time to finish the game. It was because the writer used the materials about the story of the students that give them to the material of exercise. Students should back to their deks to see the dictionary and answered the questions or solve the actions directly. This was also due to the unevenness of the number of dictionaries in each group. For example, one group could have a dictionary of 2 to 3, while the other group only had one or had not a dictionary. So, we just arranged the class to be more conducive, because the students were noisy lending to one another's dictionary.

In the third treatment as the last meeting used Interactive Board Games to the experimental group, most of the students were more active. The writers instructed the students who brought a dictionary to come forward firstly, then we divided the students who brought a dictionary equally to all groups. So, they had enough a dictionary to help answered the questions. The writers also instructed the students to make a group with the different members with the last of games. By the new rules, the students could perform well. They also not noisy, but they were not shy anymore. In the end, we had time enough to announce who the winner and who the best performance. The writers also could to evaluate the material more accessible. Based on the discussed situation of the class above, we got a conclusion that implemented Interactive Board Games or board games in a small group activity was the ideal choice for learning English, especially vocabulary. It was because they had enough chances to get more new words to remember and used in the activity. The more motivated by their selves to be the winner in the games. On the other hand, they had an active social relationship with their friends in this situation as the partners in the games.

Based on the t-test, we had the t-ratio was 8.04 with the degree of freedom (df) 50 and level of significance $(\alpha) 5 \%$, and the t-table was 1.68 . This means that the $t$-count was higher than the $t$-table. So, the null hypothesis $\left(\mathrm{H}_{0}\right)$ was rejected, whereas the hypothesis of the research $\left(\mathrm{H}_{1}\right)$ was accepted. In other words, the students who were taught using IBG performed better vocabulary achievement than students who were not taught using those games.

\section{Conclusion}

Based on the discussion, we conclude that the Interactive Board Games are good to use in class. However, teachers should not use the games too much. The implemented Interactive Board Games in a small group activity is an ideal choice for learning English, especially to vocabulary achievement. It is because students are more active in learning, and can push their memories to new words. On the other hand, the used Interactive Board Games in vocabulary learning make the students be more motivated by themselves since the students eager to be a winner. They also have an active social relationship with their friends as partners in the games. In order to use Interactive Board Games during learning English in class, the teacher should have extra energy to guide and give instruction to the students to get a conducive atmosphere. Uncontrol and chaotic class should be avoided. The teacher also has to prepare many materials if the teacher wants to use the games for two or more in class. Besides that, the teacher should know to design the games to made the students more interested and not felt bored, such as media, groups, facilities, etc. 
Based on the explanation that has been described above, students who taught by using Interactive Board Games are more active, confident, enthusiastic, and motivated than the students who not taught by using Interactive Board Games in learning English activities, especially in the exercise of English learning to vocabulary achievement. We give recommendations for teachers around the world to be not hesitated to use IBG for improving student's vocabulary. Also, we suggest further research to investigate the effect of this game on other skills such as speaking, writing, listening.

\section{References}

Biemiller, A. (2004). Teaching vocabulary in the primary grades: Vocabulary instruction needed. Vocabulary Instruction: Research to Practice, 28-40.

Branch, R. M. (2009). Instructional design: The ADDIE approach (Vol. 722). Springer Science \& Business Media.

Cahyono, B. Y. (2015). The Teaching ff EFL Vocabulary in The Indonesian Context: The State of The Art. TEFLIN Journal, 19(1), 1-17.

Destianingsih, A., Satria, A., English, B., Program, S., Bengkalis, P. N., English, B., ... Bengkalis, P. N. (2017). A study on the effectiveness of using alphabet cards game in teaching vocabulary for commercial business administration students. 4 th UAD TEFL International Conference, (2012), 54-64.

Dewaele, J.-M., \& Thirtle, H. (2009). Why do some young learners drop foreign languages? A focus on learner-internal variables. International Journal of Bilingual Education and Bilingualism, 12(6), 635-649.

Durden, T. R., Dangel, J. R., Durden, T., \& Dangel, J. R. (2008). Teacher-involved conversations with young children during small group activity children during small group activity. 28(3), 251-266. https:/ / doi.org/10.1080/09575140802393793

Evelyn, H., \& Brown, C. (1995). Vocabulary, Semantics and Language Education. Cambridge: Cambridge University Press.

Hur, J. W., \& Suh, S. (2012). Making Learning Active with Interactive Whiteboards, Podcasts, and Digital Storytelling in ELL Classrooms. Computers in the Schools, 29(4), 320-338. https:/ / doi.org/10.1080/07380569.2012.734275

Huyen, N. T. T., \& Nga, K. T. T. (2003). Learning vocabulary through games. Asian EFL Journal, 5(4), 90-105.

Montgomery, J. K. (2007). The following information was based on information from Judy K. Montgomery's book: The Bridge of Vocabulary: Evidence Based Activities for Academic Success. NCS Pearson Inc.

Nation, P. (2002). Best practice in vocabulary teaching and learning. Methodology in Language Teaching: An Anthology of Current Practice, 267-272.

Ramani, G. B., Siegler, R. S., \& Hitti, A. (2012). Taking It to the Classroom : Number Board Games as a Small Group Learning Activity. Journal of Educational Psychology, 104(3), 661-672. https:// doi.org/10.1037/a0028995

Reza, M. (2012). Improving Vocabulary Learning in Foreign Language Learning 
Through Reciprocal Teaching Strategy. International Journal of Learning $\mathcal{E}$ Development, 2(6), 186-201. https:/ / doi.org/10.5296/ijld.v2i6.2882

Richards, J. C., \& Renandya, W. A. (2002). Methodology in language teaching: An anthology of current practice. Cambridge university press.

Rohmatillah. (2014). A Study on Students' Difficulties in Learning Vocabulary Rohmatillah Institut Agama Islam Negeri (IAIN) Raden Intan Lampung. English Education: Jurnal Tadris Bahasa Inggris, 6(1), 69-86.

Wasik, B. (2014). When Fewer Is More: Small Groups in Early Childhood Classrooms. 35(September), 515-521. https://doi.org/10.1007/s10643-008-0245-4

Young, S. S.-C., \& Wang, Y.-H. (2014). The game embedded CALL system to facilitate English vocabulary acquisition and pronunciation. Journal of Educational Technology \& Society, 17(3), 239-251. 